\title{
APLIKASI KOMPOS LIMBAH KULIT BUAH KAKAO DAN JARAK TANAM BERBEDA TERHADAP PERTUMBUHAN TANAMAN TERUBUK (Saccharum edule Hasskarl)
}

\author{
Ramadhani Chaniago ${ }^{1}$ dan Darni Lamusu ${ }^{1}$ \\ ${ }^{1}$ Program Studi Agroteknologi Fakultas Pertanian \\ Universitas Muhammadiyah Luwuk Kabupaten Banggai Provinsi Sulawesi Tengah Kode pos 94711 \\ e-mail : idhonchaniago@yahoo.co.id
}

\begin{abstract}
Cocoa fruit skin is a waste that can cause environmental problems around the plantation. One way to utilize the waste of cocoa fruit skin is made organic fertilizer. The use of different spacing will affect the large number of plant unity area and will indirectly affect the absorption of nutrients, water and other growth factors. The purpose of this study was to determine the effect of composting of cocoa fruit skin waste on the growth of cropped plants (Saccharum edule Hasskarl) with different plant spacing. This field experiment was conducted from July to November 2016 with research location in Kecamatan Luwuk Banggai Regency. The experimental design used was factorial in randomized block design with 2 replications, then there were 18 treatment combinations. In this research the first factor of composition of cocoa fruit skin with cow dung consisting of 3 levels namely: P1 $=50 \mathrm{~kg}$ of compost: $10 \mathrm{~kg}$ of cow dung; $\mathrm{P} 2=50 \mathrm{~kg}: 30 \mathrm{~kg} ; \mathrm{P} 3=50 \mathrm{~kg}$ : 50 . While the second factor are plant spacing consisting of 3 levels, namely: $\mathrm{J} 1=100 \mathrm{~cm} \mathrm{X} 150 \mathrm{~cm} ; \mathrm{J} 2=100 \mathrm{~cm}$ $X 100 \mathrm{~cm} ; \mathrm{J} 3=100 \mathrm{~cm}$ X $50 \mathrm{~cm}$. Based on the result obtained, It showed that the treatment of $50 \mathrm{~kg}$ of cocoa fruit skin compost with $50 \mathrm{~kg}$ of cow dung (P3) gave the best shoot effect on 5 weeks after planting (WAP), to the best plant height that is P2 treatment on 3 (WAP), and the best leaf length is P2 treatment on 2 up to 4(WAP).
\end{abstract}

Key words : Compost, Plant Spacing, Terubuk

(C) 2018 Ramadhani Chaniago, Darni Lamusu

\section{PENDAHULUAN}

Terubuk (Saccharum edule Hasskarl) sayuran indigenous, yang sampai saat ini masih dibudidayakan secara perbanyakan vegetatif menggunakan stek batang dengan areal yang tidak luas, karena bunga terubuk tidak normal dan tidak dapat berkembang sempurna sampai membentuk biji. Sayuran ini memiliki potensi ekonomi yang sangat besar (Daulay et al., 1984). Perbanyakan dengan menggunakan setek batang memerlukan bahan tanam dalam jumlah banyak, waktu yang lama dan areal penanaman yang luas. Hasil yang didapat dari perbanyakan konvensional adalah antara 7-22 tunas per setek 2 buku tanaman terubuk berumur antara 7-22 minggu dengan jarak tanam $70 \mathrm{~cm} \times 70 \mathrm{~cm}$, jumlah bunga per rumpun yang berisi 14 tanaman antara 14-108 bunga terubuk (Kurriatussolihat , 2009; Jannah , 2011).

Tanaman terubuk tumbuh subur pada kondisi tanah yang subur dengan $\mathrm{pH}$ sekitar 56. Tanaman ini termasuk tanaman hari pendek (Short day photoperiod), dimana membutuhkan lama penyinaran kurang dari 12 jam sehari. Alasan sayuran ini dibudidayakan masih secara perbanyakan vegetatif antara lain kurang tersedianya benih/bibit, kurang informasi teknologi budidaya, kurang informasi tentang kesesuaian sayuran dengan sistem produksi yang ada. Peningkatan produksi juga mempengaruhi produktifitas suatu komoditi termasuk tanaman terubuk. Salah satu cara untuk meningkatkan produksi yaitu dengan cara pemupukan yang berbahan dasar limbah perkebunan. 
Salah satu limbah pertanian yang baru sedikit dimanfaatkan adalah limbah dari perkebunan kakao yaitu kulit buah kakao. Opeke (1984) mengemukakan bahwa kulit buah kakao mengandung protein 9,69\%, glukosa $1,16 \%$, sukrosa $0,18 \%$, pektin $5,30 \%$, dan Theobromin 0,20\%. Kulit buah kakao merupakan salah satu limbah yang apabila tidak dimanfaatkan dapat menimbulkan masalah lingkungan disekitar perkebunan. Salah satu cara untuk memanfaatkan kulit buah kakao adalah dijadikan kompos yang dapat digunakan sebagai pupuk organik (Goenadi, 1997).

Menurut Darmono dan Tri Panji (1999), limbah kulit buah kakao yang dihasilkan dalam jumlah banyak akan menjadi masalah jika tidak ditangani dengan baik. Produksi limbah padat ini mencapai sekitar $60 \%$ dari total produksi buah. Spillane (1995) mengemukakan bahwa kulit buah kakao dapat dimanfaatkan sebagai sumber unsur hara tanaman dalam bentuk kompos, pakan ternak, produksi biogas dan sumber pektin. Sebagai bahan organik, kulit buah kakao mempunyai komposisi hara dan senyawa yang sangat potensial sebagai medium tumbuh tanaman. Kadar air untuk kakao lindak sekitar $86 \%$, dan kadar bahan organiknya sekitar 55,7\% (Soedarsono et al, 1997). Gunadi dan Yufnal (2004) menyatakan bahwa kompos kulit buah kakao mempunyai $\mathrm{pH} 5,4, \mathrm{~N}$ total $1,30 \%, \mathrm{C}$ organik $33,71 \%, \mathrm{P}_{2} \mathrm{O}_{5} 0,186 \%, \mathrm{~K}_{2} \mathrm{O}$ $5,5 \%, \mathrm{CaO} 0,23 \%$, dan $\mathrm{MgO} 0,59 \%$.

Selain pemupukan, penggunaan jarak tanam yang berbeda-beda akan berpengaruh terhadap banyaknya populasi tanaman per satuan luas dan secara tidak langsung akan berpengaruh terhadap penyerapan unsur hara, air dan faktor tumbuh lainnya. Pada jarak tanam antar barisan yang terlalu rapat akan terjadi persaingan antara tanaman dalam menggunakan air, unsur hara dan cahaya matahari, juga menyulitkan dalam pelaksanaan penanaman dan pemeliharaan tanaman. Sedangkan pada jarak tanam antar barisan yang lebih lebar akan berpengaruh terhadap efisiensi penggunaan tempat dan pemberian pupuk.
Petani di daerah Kabupaten Banggai belum melakukan pemupukan terhadap tanaman terubuk. Tujuan dari penelitian ini adalah untuk mengetahui pengaruh pemberian kompos dari kompos kulit buah kakao pada pertumbuhan dan produksi tanaman terubuk (Saccarum edule Hasskarl) dengan jarak tanam yang berbeda.

\section{BAHAN DAN METODA}

Penelitian ini dilaksanakan pada bulan Juli - November tahun 2016 dengan lokasi penelitian di Dusun III Desa Lumpoknyo Kecamatan Luwuk Kabupaten Banggai.

Alat yang digunakan antara lain : karung, penggaris (meteran), jangka sorong, kamera, timbangan analitik, alat tulis. sedangkan bahan yang digunakan, yaitu adalah stek terubuk, kompos limbah kulit buah kakao dan kotoran sapi.

Metode yang digunakan adalah metode eksperimen. Rancangan percobaan yang digunakan adalah Rancangan Acak Kelompok (RAK) dua faktor dengan 2 kali ulangan, maka ada 18 kombinasi perlakuan. Dalam penelitian ini faktor pertaman menggunakan perbandingan kompos kulit buah kakao dengan kotoran sapi yang terdiri dari 3 taraf yaitu : $\mathrm{P} 1=50 \mathrm{~kg}$ limbah kulit buah kakao : $10 \mathrm{~kg}$ kotoran sapi; P2 $=50 \mathrm{~kg}$ limbah kulit buah kakao : $30 \mathrm{~kg}$ kotoran sapi; P3 = $50 \mathrm{~kg}$ limbah kulit buah kakao : $50 \mathrm{~kg}$ kotoran sapi. Sedangkan faktor kedua menggunakan jarak tanam yang terdiri dari 3 taraf, yaitu: $\mathrm{J} 1=100$ $\mathrm{cm} \mathrm{X} 150 \mathrm{~cm} ; \mathrm{J} 2=100 \mathrm{~cm}$ X $100 \mathrm{~cm} ; \mathrm{J} 3=100$ $\mathrm{cm} \mathrm{X} \quad 50 \mathrm{~cm}$. Kombinasi perlakuan yang dicobakan adalah sebagai berikut : P1J1, P2J1, P3J1, P1J2, P2J2, P3J2, P1J3, P2J3, dan P3J3.

Adapun langkah-langkah dalam penelitian ini adalah sebagai berikut :

Persiapan Bahan, Bahan stek yang digunakan adalah stek 3 buku. Bahan stek ditanam dengan posisi horizontal di bedengan yang berukuran 4 $\mathrm{m} \times 1 \mathrm{~m}$. Bedengan sebelumnya telah diolah. Stek ditanam sesuai dengan perlakuan.

Pemeliharaan, dilakukan meliputi penyiraman sebanyak 2 kali dalam satu minggu, penyulaman, pengendalian hama, penyiangan gulma dan pembuangan daun tua. Penyiraman dilakukan pada awal tanam dan apabila kondisi 
tanah kering. Penyiangan gulma dilakukan dengan cara mencabut gulma dengan tangan. Pembuangan daun tua dilakukan untuk mengendalikan serangan penyakit dan tanaman rebah.

Panen, dimulai dilakukan pada bulan ke lima atau ke enam setelah tanam. Bagian tanaman yang dipanen adalah bunga yang tertutup kelobot. Adapun ciri bunga yang telah siap panen yaitu saat bunga telah mengisi hampir seluruh ruang kosong yang tertutup kelobot.

Sedangkan Pengamatan, dilakukan selama penelitian berlangsung merupakan pengamatan kuantitatif yang terdiri atas : Jumlah tunas, yang diamati merupakan jumlah semua tunas yang tumbuh pada bahan stek yang ditanam. Pengamatan ini dilakukan setiap minggunya. Tinggi tanaman, diukur dari pangkal batang sampai pada ujung daun terakhir. Pengukuran dilakukan setiap minggunya. Panjang daun, diukur dari pangkal daun sampai ujung daun yang terbentuk sempurna. Pengukurannya dilakukan setiap minggunya. Jumlah pelepah daun, dihitung setiap pelepah daun yang terbentuk sempurna. Pengukurannya dilakukan setiap minggunya. Waktu panen, dihitung mulai tanam hingga saat pemanenan bunga. Bobot bunga, Pengukuran bobot bunga dilakukan terhadap bunga yang telah dikupas atau dibersihkan dari klobot. Penimbangan dilakukan langsung setelah bunga dipanen dengan menggunakan timbangan digital.

\section{HASIL DAN PEMBAHASAN}

Kompos kulit buah kakao dengan kotoran sapi mempunyai $\mathrm{N}$ total $0,25 \%$, $\mathrm{P}_{2} \mathrm{O}_{5} 3,91 \%, \mathrm{~K}_{2} \mathrm{O} 5,23 \%$. Hasil sidik ragam dari data penelitian menunjukkan bahwa kompos kulit buah kakao dengan kotoran sapi berpengaruh nyata terhadap jumlah tunas pada 5 MST, berpengaruh nyata tinggi tanaman pada 4 MST, serta berpengaruh sangat nyata terhadap panjang daun pada 2 MST dan berpengaruh nyata terhadap panjang daun pada 3-4 MST. Sedangan perlakuan jarak tanaman dan Interaksi dari kedua perlakuan berpengaruh tidak nyata terhadap semua variabel pengamatan.

\section{Jumlah Tunas}

Data rataan jumlah tunas tanaman terubuk pada berbagai kompos kulit buah kakao dengan kotoran sapi dan jarak tanam berbeda dapat dilihat pada Tabel 1 .

Tabel 1. Rataan Jumlah Tunas tanaman terubuk pada perlakuan kompos kulit buah kakao dengan kotoran sapi dan jarak tanam berbeda 5 MST

\begin{tabular}{cccccc}
\hline \multirow{2}{*}{ MST } & Kompos & \multicolumn{3}{c}{$\begin{array}{c}\text { Jarak Tanam } \\
(\mathrm{cm})\end{array}$} & Rataan \\
\cline { 3 - 5 } & $(\mathrm{Kg})$ & $\mathrm{J} 1$ & $\mathrm{~J} 2$ & $\mathrm{J3}$ & \\
\hline \multirow{3}{*}{5} & $\mathrm{P} 1(50: 10)$ & 3,33 & 2,00 & 3,33 & $2,89 \mathrm{a}$ \\
& $\mathrm{P} 2(50: 30)$ & 4,00 & 3,67 & 3,33 & $3,67 \mathrm{a}$ \\
& $\mathrm{P} 3(50: 50)$ & 4,33 & 3,67 & 5,00 & $4,33 \mathrm{~b}$ \\
\hline & Rataan & 3,89 & 3,11 & 3,89 & \\
\hline
\end{tabular}

Keterangan : Angka-angka yang diikuti huruf yang berbeda pada kolom yang sama menunjukkan berbeda nyata menurut Uji Beda Terkecil (BNT) pada $\alpha=0,05$.

Tabel 1 menunjukkan bahwa jumlah tunas tertinggi terdapat pada perlakuan (P3) kompos kulit buah kakao dengan kotoran sapi $(50 \mathrm{~kg}: 50 \mathrm{~kg})$ yaitu 4,33 tunas. Jumlah tunas terendah terdapat pada perlakuan (P1) kompos kulit buah kakao dengan kotoran sapi $(50 \mathrm{~kg}$ :
$10 \mathrm{~kg}$ ) yaitu 2,89 tunas, berbeda nyata dengan perlakuan kompos kulit buah kakao dengan kotoran sapi $(50 \mathrm{~kg}: 30 \mathrm{~kg})$ dan $(50 \mathrm{~kg}: 50$ $\mathrm{kg}$ ). Perlakuan (P1) berbeda nyata dengan (P3), tetapi berbeda tidak nyata dengan (P2). Hal ini disebabkan oleh unsur hara yang terdapat pada 
kompos kulit buah kakao dengan kotoran sapi dapat merangsang pertumbuhan tunas secara cepat karena kompos ini menyediakan unsur hara esensial seperti Phosfor (P) dan Kalium (K) yang memenuhi standar mutu kompos dari SNI 19-7030-2004.

Chaniago dan Ramlan (2015) dalam penelitiannya menyatakan bahwa kompos kulit buah kakao dengan kotoran sapi mempunyai $\mathrm{N}$ total $0,25 \%, \mathrm{P}_{2} \mathrm{O}_{5} 3,91 \%$, $\mathrm{K}_{2} \mathrm{O} 5,23 \%$. Selanjutnya menurut Wudianto (2002) hara yang dapat mempengaruhi jumlah tunas adalah unsur kalium. Tanaman bila mendapatkan kalium yang cukup maka tunas akan tumbuh dengan baik karena fungsi kalium dalam tanaman dapat merangsang jaringan meristematik yang memungkinkan bertambahnya jumlah tunas.

\section{Tinggi Tanaman}

Data rataan tinggi tanaman terubuk pada kompos kulit buah kakao dengan kotoran sapi dan jarak tanam berbeda 3 MST dapat dilihat pada Tabel 2 .

Tabel 2 menunjukkan bahwa tinggi tanaman terubuk 3 MST tertinggi terdapat pada perlakuan (P2) kompos kulit buah kakao dengan kotoran sapi (50 kg : $30 \mathrm{~kg}$ ) yaitu 36,14 cm. Tinggi tanaman terendah terdapat pada perlakuan (P1) kompos kulit buah kakao dengan kotoran sapi (50 kg : $10 \mathrm{~kg}$ ) yaitu 16,71 $\mathrm{cm}$. Perlakuan (P1) berbeda nyata dengan (P2), tetapi berbeda tidak nyata dengan (P3). Hal ini diduga karena kandungan Phosfor dan Kalium pada kompos kulit buah kakao dengan kotoran sapi telah melebihi dari standar mutu kompos SNI 19-7030-2004 yaitu $\mathrm{P}=0,10 \%$ dan $\mathrm{K}=$ $1,20 \%$, sehingga dapat memenuhi kebutuhan hara $\mathrm{P}$ dan $\mathrm{K}$ pada tanaman terubuk.

Pasokan unsur $\mathrm{P}$ yang cukup mengakibatkan pertumbuhan perakaran meningkat, sehingga serapan hara dan air meningkat. Oleh karena itu, fungsi unsur $\mathrm{P}$ yang sangat penting untuk pertumbuhan dan metabolisme tanaman, kekurangan unsur $\mathrm{P}$ sangat menghambat pembelahan sel dan pengembangan sel, respirasi dan fotosintesis (Havlin, 2005). Sedangkan menurut Marsono (2001), bahwa kalium unsur hara esensial sangat berperan dalam pembentukan organ tanaman seperti batang, akar, dan daun. Kalium juga berfungsi sebagai perangsang jaringan meristematik yang memungkinkan bertambah tingginya batang tanaman.

Tabel 2. Rataan tinggi tanaman terubuk pada kompos kulit buah kakao dengan kotoran sapi dan jarak tanam berbeda 3 MST

\begin{tabular}{|c|c|c|c|c|c|}
\hline \multirow{2}{*}{ MST } & \multirow{2}{*}{$\begin{array}{c}\text { Kompos } \\
(\mathrm{Kg})\end{array}$} & \multicolumn{3}{|c|}{$\begin{array}{c}\text { Jarak Tanam } \\
(\mathrm{Cm})\end{array}$} & \multirow[t]{2}{*}{ Rataan } \\
\hline & & $\begin{array}{c}\mathrm{J} 1 \\
(100 \mathrm{X} 150)\end{array}$ & $\begin{array}{c}\mathrm{J} 2 \\
(100 \times 100)\end{array}$ & $\begin{array}{c}\mathrm{J} 3 \\
(100 \times 50)\end{array}$ & \\
\hline \multirow{4}{*}{3} & P1 $(50: 10)$ & 19,58 & 17,83 & 12,72 & $16,71 \mathrm{a}$ \\
\hline & $\mathrm{P} 2(50: 30)$ & 40,42 & 38,42 & 29,58 & $36,14 b$ \\
\hline & $\mathrm{P} 3(50: 50)$ & 14,61 & 27,60 & 39,67 & $27,29 a$ \\
\hline & Rataan & 24,87 & 27,95 & 27,32 & \\
\hline
\end{tabular}

Keterangan : Angka-angka yang diikuti huruf yang berbeda pada kolom yang sama menunjukkan berbeda nyata menurut Uji Beda Terkecil (BNT) pada $\alpha=0,05$.

\section{Panjang Daun}

Data rataan panjang daun terubuk kompos kulit buah kakao dengan kotoran sapi dan jarak tanam berbeda 2 sampai 4 MST dapat dilihat pada Tabel 3 . 
Tabel 3. Rataan panjang daun terubuk kompos kulit buah kakao dengan kotoran sapi dan jarak tanam berbeda 2 sampai 4 MST

\begin{tabular}{|c|c|c|c|c|c|}
\hline \multirow{2}{*}{ MST } & \multirow{2}{*}{$\begin{array}{c}\text { Kompos } \\
\text { (Kg) }\end{array}$} & \multicolumn{3}{|c|}{$\begin{array}{l}\text { Jarak Tanam } \\
(\mathrm{Cm})\end{array}$} & \multirow[t]{2}{*}{ Rataan } \\
\hline & & $\begin{array}{c}\mathrm{J} 1 \\
(100 \times 150)\end{array}$ & $\begin{array}{c}\mathrm{J} 2 \\
(100 \times 100)\end{array}$ & $\begin{array}{c}\mathrm{J} 3 \\
(100 \times 50)\end{array}$ & \\
\hline \multirow{4}{*}{2} & $\mathrm{P} 1(50: 10)$ & 7,00 & 7,00 & 7,00 & $7,00 \quad a$ \\
\hline & $\mathrm{P} 2(50: 30)$ & 14,00 & 15,00 & 13,00 & $14,00 \mathrm{c}$ \\
\hline & $\mathrm{P} 3(50: 50)$ & 7,00 & 11,00 & 17,00 & $11,67 \mathrm{~b}$ \\
\hline & Rataan & 9,33 & 11,00 & 12,33 & \\
\hline \multirow{4}{*}{3} & $\mathrm{P} 1(50: 10)$ & 14,00 & 12,00 & 13,67 & $13,22 \mathrm{a}$ \\
\hline & $\mathrm{P} 2(50: 30)$ & 32,00 & 33,17 & 21,43 & $28,87 \mathrm{~b}$ \\
\hline & $\mathrm{P} 3(50: 50)$ & 14,00 & 24,00 & 36,17 & $24,72 \mathrm{a}$ \\
\hline & Rataan & 20,00 & 23,06 & 23,76 & \\
\hline \multirow{4}{*}{4} & $\mathrm{P} 1(50: 10)$ & 23,67 & 15,67 & 13,83 & $17,79 \mathrm{a}$ \\
\hline & $\mathrm{P} 2(50: 30)$ & 39,33 & 40,50 & 36,00 & $38,61 \mathrm{~b}$ \\
\hline & $\mathrm{P} 3(50: 50)$ & 18,50 & 29,17 & 45,73 & $31,13 \mathrm{a}$ \\
\hline & Rataan & 27,17 & 28,51 & 31,85 & \\
\hline
\end{tabular}

Keterangan : Angka-angka yang diikuti huruf yang berbeda pada kolom yang sama menunjukkan berbeda nyata menurut Uji Beda Terkecil (BNT) pada $\alpha=0,05$.

Tabel 3 menunjukkan bahwa panjang daun terubuk 2 MST tertinggi terdapat pada perlakuan (P2) kompos kulit buah kakao dengan kotoran sapi $(50 \mathrm{~kg}: 30 \mathrm{~kg})$ yaitu 14 $\mathrm{cm}$. Panjang daun tanaman terendah terdapat pada perlakuan (P1) kompos kulit buah kakao dengan kotoran sapi (50 kg: $10 \mathrm{~kg}$ ) yaitu $7 \mathrm{~cm}$. Perlakuan (P1) berbeda nyata dengan (P2) dan (P3).

Tabel 3 menunjukkan bahwa panjang daun tanaman terubuk 3 dan 4 MST tertinggi terdapat pada perlakuan (P2) kompos kulit buah kakao dengan kotoran sapi $(50 \mathrm{~kg}: 30 \mathrm{~kg})$ yaitu $28,87 \mathrm{~cm}$ dan $38,61 \mathrm{~cm}$. Panjang daun tanaman terendah terdapat pada perlakuan (P1) kompos kulit buah kakao dengan kotoran sapi (50 kg : $10 \mathrm{~kg}$ ) yaitu $13,22 \mathrm{~cm}$ dan $17,79 \mathrm{~cm}$. Perlakuan (P1) berbeda nyata dengan (P2), tetapi berbeda tidak nyata dengan (P3). Hal ini diduga karena tersedianya unsur Nitrogen $(\mathrm{N})$ pada kompos kulit buah kakao dengan kotoran sapi, sehingga tanaman terubuk dapat memberikan respon terhadap panjang daun.

Unsur Nitrogen (N) berfungsi merangsang pertumbuhan tanaman secara keseluruhan, untuk sintesa asam amino dan protein dalam tanaman. Merangsang pertumbuhan vegetatif (warna hijau daun, panjang daun, lebar daun) dan pertumbuhan vegetatif batang (tinggi dan ukuran batang) (Kloepper, J.W, 1993). Selanjutnya Nyakpa dkk, (1988) menambahkan bahwa proses pembentukan daun tidak terlepas dari peranan unsur hara seperti nitrogen dan fosfor yang terdapat pada medium tanah dan tersedia bagi tanaman. Secara umum apabila tanaman kekurangan unsur hara tersebut akan mengganggu kegiatan metabolisme tanaman sehingga proses pembentukan daun yang baru akan terhambat. Kemudian Lakitan (1996) menyatakan bahwa tanaman yang tidak mendapat tambahan nitrogen akan tumbuh kerdil serta daun yang terbentuk lebih kecil, tipis dan jumlahnya akan sedikit sedangkan tanaman yang mendapatkan unsur nitrogen yang cukup maka daun yang terbentuk akan lebih banyak dan lebar.

\section{Jumlah Pelepah Daun}

Data rataan jumlah pelepah daun terubuk pada berbagai kompos kulit buah kakao dengan kotoran sapi dan jarak tanam dapat dilihat pada Tabel 4.

Tabel 4 menunjukkan bahwa jumlah pelepah daun tertinggi terdapat pada perlakuan (P3) kompos kulit buah kakao dengan kotoran 
sapi $(50 \mathrm{~kg}$ : $50 \mathrm{~kg}$ ) yaitu 5,56 helai. Jumlah pelepah daun terendah terdapat pada perlakuan (P1) kompos kulit buah kakao dengan kotoran sapi $(50 \mathrm{~kg}$ : $10 \mathrm{~kg})$ yaitu 3,78 helai. Hal ini menunjukan bahwa tanaman terubuk memberikan respon terhadap pemupukan, seperti ditunjukkan pada tabel 3 bahwa semakin tinggi pemberian kompos maka semakin banyak jumlah pelepah daunnya.

Nyakpa, dkk (1988) menyatakan bahwa proses pembentukan daun tidak terlepas dari peranan unsur hara seperti nitrogen dan fosfor yang terdapat pada tanah dan tersedia bagi tanaman. Kedua unsur ini berperan dalam pembentukan sel-sel baru dan komponen utama penyusun senyawa organik dalam tanaman seperti asam amino, asam nukleat, klorofil, ADP dan ATP. Apabila tanaman defisiensi untuk kedua unsur hara tersebut maka metabolisme tanaman akan terganggu sehingga proses pembentukan daun menjadi terlambat. Banyaknya unsur hara yang diserap oleh tanaman dari tanah berpengaruh dalam proses pembentukan daun karena pembentukan sel-sel baru dalam suatu tanaman sangat erat hubungannya dengan hara yang ada dalam tanaman.

Tabel 4. Rataan jumlah pelepah daun terubuk kompos kulit buah kakao dengan kotoran sapi dan jarak tanam berbeda

\begin{tabular}{ccccc}
\hline & \multicolumn{3}{c}{$\begin{array}{c}\text { Jarak Tanam } \\
(\mathrm{Cm})\end{array}$} & \multirow{2}{*}{ Rataan } \\
\cline { 2 - 4 }$(\mathrm{Kg})$ & $\mathrm{J} 1$ & $\mathrm{~J} 2$ & $\mathrm{J3}$ & \\
\hline $\mathrm{P} 1(50: 10)$ & 5,00 & 2,00 & 4,33 & 3,78 \\
$\mathrm{P} 2(50: 30)$ & 5,00 & 3,67 & 5,00 & 4,56 \\
P3 $(50: 50)$ & 4,00 & 5,00 & 7,67 & 5,56 \\
\hline Rataan & 3,89 & 3,11 & 3,89 & \\
\hline
\end{tabular}

\section{KESIMPULAN}

Berdasarkan hasil penelitian menunjukkan bahwa perlakuan kompos kulit buah kakao dengan kotoran sapi memberikan pengaruh terhadap jumlah tunas yang terbaik yaitu perlakuan P3 pada 5 MST, terhadap tinggi tanaman yang terbaik yaitu perlakuan P2 pada $3 \mathrm{MST}$, serta terhadap panjang daun yang terbaik yaitu perlakuan P2 pada 2 sampai 4 MST. Setelah melihat kesimpulan, maka penelitian ini menyarankan untuk mengaplikasikan kompos limbah kulit buah kakao dengan kotoran sapi dengan perbandingan $50: 20 \mathrm{~kg}$.

\section{UCAPAN TERIMAKASIH}

Peneliti mengucapkan terimakasih kepada Direktorat Riset dan Pengabdian Masyarakat (DRPM) Kementerian Riset, Teknologi dan Pendidikan Tinggi (KEMENRISTEK DIKTI) atas dukungan yang diberikan kepada peneliti berupa bantuan dana
Penelitian Dosen Pemula pada tahun pelaksanaan 2016 sehingga penelitian ini berjalan sesuai dengan jadwal yang telah ditentukan.

\section{DAFTAR PUSTAKA}

Badan Standarisasi Nasional (BSN). 2004. Spesifikasi Kompos dari Sampah Domestik. SNI 19-7030-2004.

Chaniago, R dan W. Ramlan. 2015. Pemanfaatan Limbah Kulit Buah Kakao Sebagai Pupuk Organik Dalam Menunjang Pertanian Berkelanjutan. Jurnal Tanah Tropika Volume 21 No 1, Januari 2016: 33-39.

Darmono dan Tri Panji. 1999. Penyediaan Kompos Kulit Buah Kakao Bebas Phytophthora palmivora. Warta Penelitian Perkebunan. V (1). : 33-38. 
Daulay, D., H. Syarief, dan L. Hidayat. 1984. Mempelajari Peningkatan Daya Simpan dan Pemanfaatan Tebu Terubuk (Saccharum edule Hassk). Jurusan Teknologi Pangan dan Gizi, Fakultas Teknologi Pertanian. Institut Pertanian Bogor.

Goenadi. 1997. Kompos Bioaktif dari Tandan Kosong Kelapa Sawit. Kumpulan Makalah Pertemuan Teknis Biotek. Perkebunan Untuk Praktek. Bogor. 1827.

Goenadi, D. H. dan A. Yufnal. 2004. Orgadek, Aktivator Pengomposan. Pengembangan Hasil Penelitian Unit Penelitian Bioteknologi. Perkebunan Bogor.

Havlin, J.L., J.D. Beaton, S.L. Nelson, W.L. Nelson. 2005. Soil Fertility and Fertilizers. An Introduction to Nutrient Management. New Jersey: Pearson Prentice Hall.

Jannah, U.F. 2011. Penetapan Dosis Pupuk N, $\mathrm{P}$, dan K Terubuk (Saccharum edule Hasskarl) [Makalah Seminar]. Bogor: Program Pascasarjana, Institut Pertanian Bogor.

Kuriatussholihat N. 2009. Pengaruh Bahan Stek dan Pemupukan Terhadap Produksi Terubuk [skripsi]. Bogor:Fakultas Pertanian, Institut Pertanian Bogor.

Kloepper, J.W. 1993. Plant growth-promoting rhizobacteria as biological control agents. p. 255-274. In F.Blaine
Metting, Jr. (Ed.). Soil Microbiology Ecology, Applications in Agricultural and Environmental Management. Marcel Dekker, Inc., New York.

Lakitan, B. 1996. Fisiologi Pertumbuhan dan Perkembangan Tanaman. PT. Raja Grafindo Persada. Jakarta.

Marsono, S. 2001, Pengantar Fisiologi Tumbuhan, Gramedia, Jakarta. 231 hal.

Martin, F. 1984. Saccharum edule Hasskarl. (http://ecocrop.fao.org).

Nyakpa, M.Y., A.M. Lubis, M.A. Pulung, A.G. Amroh, A. Munawar, G.B. Hong dan N. Hakim 1986. Dasar-dasar Ilmu Tanah. Universitas Lampung. Lampung.

Opeke, L.K. 1984. Optimising Economic Returns (Profit) from Cacao Cultivation Through Efficient Use of Cocoa By Products. Proseding. $9^{\text {th }}$ International Cocoa Research Conference.

Soedarsono, S. Abdoellah, E. Aulistyowati. 1997. Penebaran Kulit Buah Kakao Sebagai Sumber Bahan Organik Tanah dan Pengaruhnya terhadap Produksi Kakao. Pelita Perkebunan 13(2):90-99.

Spillane, J. 1995. Komoditi Kakao, Peranannya dalam Perekonomian Indonesia. Kanisius. Yogyakarta.

Wudianto, R. 2002. Setek Batang Tanaman Perkebunan. Pusat Penelitian Tanaman Perkebunan. Jakarta. Hal: 54. 